Canadian

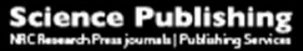

Botany

Botanique

\title{
Fungi associated with hibernating bats in New Brunswick caves: the genus Leuconeurospora
}

\begin{tabular}{|r|l|}
\hline Journal: & Botany \\
\hline Manuscript ID & cjb-2016-0086.R1 \\
\hline Danuscript Type: & Article \\
\hline Complete List of Authors: & $\begin{array}{l}\text { Malloch, David; New Brunswick Museum, Botany } \\
\text { Sigler, Lynne; University of Alberta } \\
\text { Hambleton, Sarah; Agriculture and Agri-Food Canada } \\
\text { Vanderwolf, Karen; University of Wisconsin Madison } \\
\text { Gibas, Connie; University of Texas Health Sciences Center } \\
\text { McAlpine, Donald; New Brunswick Museum }\end{array}$ \\
\hline Keyword: & bats, caves, hibernating, phylogeny, mating \\
\hline & \multicolumn{2}{|l}{} \\
\hline
\end{tabular}

SCHOLARONE $^{\text {M }}$

Manuscripts 


\section{Fungi associated with hibernating bats in New Brunswick caves: the genus Leuconeurospora} David Malloch

New Brunswick Museum, 277 Douglas Avenue, Saint John, New Brunswick, Canada E2K 1 E5.

Department of Ecology and Evolutionary Biology, University of Toronto, Toronto, Ontario, Canada M5S 3B2. dmalloch@xplornet.com, Corresponding author: Tel. +1 506 659-1099, FAX, +1 506 643-6081

Lynne Sigler

University of Alberta Microfungus Collection and Herbarium and Biological Sciences, Edmonton, Alberta, Canada T6G 2R3. Iynne.sigler@ualberta.ca

Sarah Hambleton

Ottawa Research and Development Centre, Agriculture and Agri-Food Canada, K.W. Neatby Building, 960

Carling Avenue, Ottawa, Ontario, Canada K1A 0C6. Sarah.Hambleton@AGR.GC.CA

Karen J. Vanderwolf ${ }^{1}$

New Brunswick Museum, 277 Douglas Avenue, Saint John, New Brunswick, Canada E2K 1 E5.

Canadian Wildlife Federation, 350 Promenade Michael Cowpland Drive, Kanata, Ontario Canada K2M 2W1. kjvanderw@gmail.com

Connie Fe C. Gibas ${ }^{2}$

University of Alberta Microfungus Collection and Herbarium, Edmonton, Alberta, Canada T6G $2 R 3$.

cgibas@ualberta.ca

Donald F. McAlpine

New Brunswick Museum, 277 Douglas Avenue, Saint John, New Brunswick, Canada E2K 1 E5.

Donald.McAlpine@nbm-mnb.ca

1 Present address: University of Wisconsin, 1656 Linden Drive, Madison, Wisconsin, USA, 53706

2 Present address: University of Texas Health Sciences Center, Fungus Testing Laboratory, San Antonio, Texas, USA. 78229-3900 
Abstract:Two species of Leuconeurospora, L. capsici and L. polypaeciloides (Ascomycota: Pseudeurotiaceae), are reported from the fur and skin of hibernating bats and from other substrata in caves in New Brunswick, Canada. Separate analyses using ITS, RPB1 and RPB2 DNA sequence data are in agreement and show these two species and the type species, L. pulcherrima form discrete clades within a distinct Leuconeurospora clade. The three species are distinguishable morphologically by their anamorphs, having dark conidia in L. capsici, hyaline conidia in L. polypaeciloides and no conidia in L. pulcherrima. Ascomata and ascospores are produced in $L$. pulcherrima and in mated isolates of $L$. polypaeciloides, but have not been observed in L. capsici. Leuconeurospora species are psychrotolerant, with faster growth and heavier conidial development at $7 \mathrm{C}$ than at 22 C. Of 151 bats sampled from 10 caves, 51 yielded isolates of $L$. polypaeciloides and 15 yielded $L$. capsici. The results were not uniform: neither species was isolated from bats in 3 caves, while 3 caves yielded isolates of both species and 2 yielded $L$. polypaeciloides only. These species were also isolated from cave walls and arthropods in the cave.

Key words: bats, caves, hibernating, phylogeny, mating 


\section{INTRODUCTION}

Caves have long interested mycologists because of their ecological simplicity. In most fungal habitats plants, living and dead, are major sources of nutrients. In contrast, caves are notable for their paucity of plant materials, requiring resident fungi to utilize other substrates. Vanderwolf et al. (2013b) identified several substrate preference categories among cave fungi in New Brunswick, including keratinophily, coprophily, entomophily and mycoparasitism, as well as the utilization the small amounts of plant material present such as mine timbers and penetrating mycorrhizal roots. These authors also noted that the New Brunswick cave environment favors communities of oligotrophic, psychrotolerant fungi.

The apparent recent introduction of the fungus Pseudogymnoascus destructans (Blehert \& Gargas) Minnis \& D.L. Lindner to North America and the lethal impact of white nose syndrome (WNS) on over-wintering bats has focussed attention on the dearth of information regarding fungi in cave habitats (Vanderwolf et al. 2013a), especially those fungi associated with hibernating bats. In our efforts to address this lack of knowledge in New Brunswick, Canada, we have surveyed hibernating bats and associated cave substrata over several years. Our results yielded a number of the fungi belonging to infrequently reported or undescribed taxa (Vanderwolf et al. 2013b). Among these are two species of the genus Leuconeurospora Malloch \& Cain (Ascomycota, Pseudeurotiaceae) that have been recovered repeatedly. Similarly, surveys of fungi associated with bats in caves and mines in the Unites States have identified Leuconeurospora species as components of the fungal biota (Minnis and Lindner 2013; Lorch et al. 2013; Zhang et al. 2014). Leuconeurospora species have not attracted much attention from mycologists in the past, either because their habitats have not been investigated frequently or because the methods used for their isolation have not been appropriate. Kochkina et al. (2014) recorded Leuconeurospora species from Antarctic sediments using conventional microbiological methods and metagenomic analysis.

Members of the genus Leuconeurospora are cleistothecial ascomycetes with asci and ascospores occurring in the centrum without obvious orientation. Anamorphs, when present, are represented by dichotomously branched conidiogenous structures bearing chains of conidia on apically elongating annellides. Here we describe the phylogeny, mating systems, cultural features and substrate relationships of $L$. capsici (J.F.H. Beyma) Malloch, Sigler \& Hambleton and L. polypaeciloides Malloch, Sigler \& Hambleton (Malloch 2013).

\section{MATERIALS AND METHODS}


Isolation and characterization of strains

The 10 collection sites (Table 1) included natural solution caves in limestone and gypsum, and abandoned manganese mines, all populated by over-wintering populations of the bats Myotis lucifugus, $M$. septentrionalis and small numbers of Perimyotis subflavus. Annual temperature regimes in the dark zones of these sites averaged $6.0 \pm 1.3 \mathrm{C}$ and ranged from 2.6 - 14.1 C (Vanderwolf et al. 2012). The sites are characterised by high humidity $(\mathrm{RH}>85 \%)$, and vary in length from $74 \mathrm{~m}$ (Harbell's Cave) to $332 \mathrm{~m}$ (Berryton Cave).

Following the procedures outlined by Vanderwolf et al. (2013b) hibernating bats were swabbed while roosting. The swab was then immediately streaked across duplicate plates of dextrose-peptone-yeast extract agar (DPYA) (Papavizas and Davey, 1959) and Sabouraud dextrose agar (Hawksworth et al. 1995), both containing $30 \mathrm{~m} / \mathrm{l}$ each chlortetramycin and streptomycin. DPYA also contained the growth inhibitors oxgall (5 $\mathrm{g} / \mathrm{l})$ and sodium propionate $(1 \mathrm{~g} / \mathrm{l})$. Resulting colonies were subcultured on DPYA without the antimicrobial components. All cultures were incubated at $7 \mathrm{C}$ in the dark.

Fungal samplings were carried out in 2010, before WNS or Pseudogymnoascus destructans was found in New Brunswick and in 2012, after WNS had arrived in the province (Table 2). In 2010, 10 Myotis spp. were sampled for fungi in each of 8 hibernacula. In 2012, 10 Myotis spp. were sampled in each of the 5 hibernacula, and 15 Perimyotis subflavus were sampled in 3 hibernacula (Tables 2, 3). In 2013, 6 Perimyotis subflavus were sampled in 3 hibernacula (Table 3).

In 2012 and 2013 substrates other than bats were sampled to determine whether species of Leuconeurospora occurred in the wider cave environment (Table 4). Two additional localities, Dalling's Cave and Dorchester Mine, were also sampled. The substrates included the walls of the hibernacula and arthropods within hibernacula that might serve as vectors of fungi. The hibernaculum walls were swabbed and streaked in the same way the bats were sampled. Arthropods, whole or in part, were placed directly on the isolation media.

Ten isolates determined as L. capsici and 17 isolates determined as L. polypaeciloides were accessioned in the University of Alberta Microfungus Collection and Herbarium (UAMH; https://www.uamh.ca), Edmonton, Alberta, Canada (Table 5). Cultural features were recorded for selected isolates following growth on DPYA and on malt extract agar (MEA) with peptone (Bills and Foster 2004) for 3 weeks at $7 \mathrm{C}$ and $22 \mathrm{C}$ and compared with the ex-type strains of Scopulariopsis capsici, Torula botryoides and Polypaecilum strains from other sources (Table 5). Measurements of colony diameters represent variation across all the strains. Colony color designations are according to the system of Kornerup and Wanscher (1978). Microscopic structures were 
measured in water mounts.

When infertile ascomata were observed in old cultures of several L. polypaeciloides strains, mating studies were performed on 10 isolates following the procedures of Gibas et al. (2002). A conidial inoculum of one isolate was streaked across the center of an oatmeal salts agar plate (recipe at https://www.uamh.ca//media/uamh/OrderCultures/Documents/Media.pdf ). A second isolate was streaked perpendicularly to the first. Self-self pairings were performed in the same manner. Plates were incubated at $18 \mathrm{C}$ in the dark and examined weekly for 2 months, then monthly. Final results were recorded after 6 months. Sequencing and phylogenetic analysis

DNA sequences were newly obtained for 31 fungi (Tables 5, 6). Sequences for the ITS (internal transcribed spacer) region of rDNA and two protein coding genes, the largest subunit (RPB1) and the second largest subunit (RPB2) of RNA polymerase II were determined using genomic DNA extracted from mycelium grown on potato dextrose agar (PDA, BD - Diagnostic Systems, Sparks, Maryland) with an UltraClean ${ }^{\mathrm{TM}}$ Microbial DNA Isolation Kit (MO BIO Laboratories Inc., Solana Beach, California) or the manufacturer's recommended kit for a Thermo Scientific KingFisher ML magnetic particle processor (VWR, Mississauga, Ontario). PCR was performed using the ITS primer pairs ITS5 / ITS4 (White et al. 1990) and the RNA polymerase II primers RPB1-Ac / RPB1-CR and fRPB2-5F / fRPB2-7cR (Liu et al 1999) in $10 \mu$ reactions containing $1 \mu \mathrm{L}$ of DNA, $0.5 \mu \mathrm{L}$ of $2 \mathrm{mM}$ dNTPs (Invitrogen Canada Inc. Burlington, Ontario), $0.04 \mu \mathrm{L}$ of $20 \mu \mathrm{M}$ of each primer, $0.1 \mu \mathrm{l}$ of $50 \times$ Titanium Taq DNA Polymerase and $1 \mu \mathrm{L}$ of $10 \times$ Titanium Taq buffer (BD Biosciences, Mississauga, Ontario), and 7.3 $\mathrm{LL}$ of S-HPLC H20, with the following thermal cycling conditions: $95 \mathrm{C}$ for 3 min followed by 40 cycles of $95 \mathrm{C}$ for $1 \mathrm{~min}, 58 \mathrm{C}$ for $90 \mathrm{sec}, 72 \mathrm{C}$ for $2 \mathrm{~min}$, followed by a final extension of $72 \mathrm{C}$ for 8 min. PCR products were direct-sequenced using the BigDye Terminator v. 3.1 Cycle Sequencing Reaction Kit (ABI Prism/ Applied Biosystems, Streetsville, Ontario) and the PCR primers. The reaction mix included $1.75 \mu \mathrm{l}$ $5 \times$ Buffer, $0.5 \mu \mathrm{l} 2.5 \times$ BDT sequencing Mix and $1.6 \mathrm{pmol}$ primer. Amplicons were purified by ethanol/sodium acetate precipitation and analyzed by an Applied Biosystems 3130xl Genetic Analyzer (Applied Biosystems, Streetsville, Ontario). Sequences were edited using Sequencher version 5 software (Gene Codes Corporation, Ann Arbor, Michigan).

ITS, RPB1 and RPB2 data matrices were constructed comprising the new sequences, together with representatives of the closest relatives based on published phylogenies or current BLASTN searches. Compiled sequences were submitted for alignment to the web-based utility MAFFT version 7 (http://mafft.cbrc.jp/alignment/server/) using the iterative refinement strategies Q-INS-i (ITS), in which RNA 
secondary structure is considered (Katoh and Toh 2008), or G-INS-i (RPB1 and RPB2), recommended for $<200$ sequences with global homology (Katoh et al. 2009).

Parsimony analyses were performed using PAUP software (version 4.0b10; Sinauer Associates, Inc., Sunderland Massachusetts [http://paup.csit.fsu.edu/] using the full heuristic search option and 1000 replicates of random sequence addition with gaps treated as missing data. The bootstrap (BS) percentages were determined from 100000 resamplings of the data set and random sequence addition with the number of rearrangements per replicate limited to $1 \mathrm{M}$. Bayesian analysis was performed using MrBayes software version 3.2 (Department of Scientific Computing, Florida State University, Tallahassee, Florida [see http://mrbayes.csit.fsu.edu/download.php]. Evolutionary models for each locus were determined using jModelTest 2.1.1 (Darriba et al. 2012) and ranked based on the Bayesian Information Criterion (BIC). All matrices were run using the $\mathrm{K} 2 \mathrm{P}+$ gamma evolutionary model with two independent runs using four chains each of $100,000,000$ generations, with sampling frequency every 2000 generations. The Bayesian consensus tree was directly generated after $25 \%$ burn-in. Clades that were supported by posterior probability (PP) values $\geq 85$ and $\mathrm{BS}$ values $\geq 75 \%$ were recorded.

Raw pairwise distances within the genus Leuconeurospora were calculated from the aligned data matrices using the 'ape'package (Paradis et al. 2004) for R (R CORE Team 2014) and distributions of raw pairwise intraand inter-species distances for each gene and each strain pair were plotted and overlaid using the function ggplot2 (Wickham 2009).

\section{RESULTS}

Both L. capsici and L. polypaeciloides were commonly isolated from skin and fur of hibernating bats and other substrate samples from mines and caves (Tables 2, 3, 4, 5). The genus Leuconeurospora was considered by Vanderwolf et al. (2013b) to be among the eight genera of "core fungi" isolated from the skin and fur of bats in pre-WNS New Brunswick. The other genera in this group (Pseudogymnoascus [as Geomyces], Penicillium, Mortierella, Mucor, Cephalotrichum, Cladosporium, Trichosporon) are all represented by well-known species occurring in a great variety of habitats, underlining the rather special and perhaps more restricted ecology of Leuconeurospora species.

Mating

Fertile ascomata were obtained among 7 isolates of $L$. polypaeciloides when mated on oatmeal salts agar. Ascomata were commonly produced deep within the agar and ascospore production required up to 5 months incubation. UAMH 11459 (designated + mating type strain) produced fertile ascomata with UAMH 11251 
(designated - mating type strain) and UAMH 11250, 11504 and 11513 (other - mating strains). Two other strains (UAMH 11622 and 11639 designated + mating strains) mated with - mating strains UAMH 11251 and 11250 respectively. Infertile ascomata were commonly produced by UAMH 11513 but no ascospores were observed in self-self crosses.

Cultural features

Asexual reproduction in L. capsici and L. polypaeciloides occurs by means of percurrently proliferating conidiogenenous cells marked with closely-spaced annellations (Figs. 1, 2). Fertile hyphae are hyaline, smooth, nearly coenocytic to sparsely septate, $25-125 \times 1.7-6.7 \mu \mathrm{m}$, dichotomously branched at the apex and terminated by the conidiogenous cells. Conidiogenous cells are nearly cylindrical to slightly swollen below, produced in pairs on the supporting branch and not separated from it by a septum, initially only 5-6 $\mu \mathrm{m}$ in length but gradually elongating to $50 \mu \mathrm{m}$ or more, 1.7-5.0 $\mu \mathrm{m}$ in diameter. The species differ slightly in the color of the conidia (Figs. 1, 2), in the production of ascomata (Fig. 3) and in their growth responses at different temperatures (Fig. 4). L. polypaeciloides is heterothallic, producing fertile cleistothecia between compatible mating strains and occasionally producing sterile cleistothecia when unmated.

Colony diameters of $L$. capsici after three weeks were $30-37 \mathrm{~mm}$ at $7 \mathrm{C}$ and $13-32 \mathrm{~mm}$ at $22 \mathrm{C}$ on DPYA and $28-36 \mathrm{~mm}$ at $7 \mathrm{C}$ and $12-26 \mathrm{~mm}$ at $22 \mathrm{C}$ on MEA (Fig. 4C, D). Conidial sporulation was heavy at $7 \mathrm{C}$ and 22 C (except for UAMH 11252 which was sterile at $7 \mathrm{C}$ on DPYA. Sporulation was absent at $7 \mathrm{C}$ and slight to absent at $22 \mathrm{C}$ on MEA. Conidia were obovate to obpyriform, truncate at the point of attachment, often notably broadest above the middle and appearing subtruncate at the apex (Fig. 1), Conidia were Grayish green to Dark green (28EF4) in mass and by transmitted light, smooth, 7.4-9.3 X 5.5-9.2 $\mu \mathrm{m}(\mathrm{x}=8.4 \mathrm{X} 6.9), \mathrm{D} / \mathrm{d}=0.96-1.45(\mathrm{x}$ $=1.23)$. Ascomata were not seen.

Colonies of $L$. polypaeciloides after three weeks were $30-40 \mathrm{~mm}$ at $7 \mathrm{C}$ and $17-40 \mathrm{~mm}$ on DYPA at $22 \mathrm{C}$; and $34-40 \mathrm{~mm}$ at $7 \mathrm{C}$ and $11-30 \mathrm{~mm}$ on MEA at $22 \mathrm{C}$ (Fig. 4). Conidial production was heavy at $7 \mathrm{C}$ and sparse to light at $22 \mathrm{C}$ on DPYA but slight to absent at both temperatures on MEA. Conidia were obovate, truncate at the point of attachment, hyaline in mass and by transmitted light, smooth, 6.3-10.1 X 4.9-6.6 $\mu \mathrm{m}(\mathrm{x}=8.4 \times 5.9)$, $\mathrm{D} / \mathrm{d}=1.24-1.53(\mathrm{x}=1.42)$ (Fig. 2). Cleistothecia were spherical, glabrous or with undifferentiated hyphal attachment, reddish brown by transmitted light and black by reflected light, with a conspicuously cephalothecoid peridium (Fig. 3). The peridium was composed of dehiscent plates of cells $25-50 \mu \mathrm{m}$ in diameter, with individual cells nearly isometric at the centre of the plates and elongated to $16 \mu \mathrm{m}$ toward the periphery, 2.5-9.0 $\mu \mathrm{m}$ in diameter. The ascogenous system filled the centrum and was composed of dichotomously branched hyphae 
4.0-6.8 $\mu \mathrm{m}$ in diameter, bearing asci at the tips of the branches. Asci were spherical to subspherical, 10.8-16.7 $\mu \mathrm{m}$ in diameter, thin-walled, 8-spored, evanescent, releasing the ascospores into the centrum. Ascospores were ellipsoidal to fusoid, 4.9-6.7 X 3.5-4.1 $\mu \mathrm{m}(\mathrm{x}=5.9 \times 3.8 \mu \mathrm{m}), \mathrm{D} / \mathrm{d}=1.29-1.73(\mathrm{x}=1.55)$, appearing rather pointed at the poles, hyaline, and marked by several low anastomosing ridges up to $1 \mu \mathrm{m}$ high forming a loose network. Arthroconidia were produced mainly below the surface of the medium and frequently in association with the ascomata (Fig. 3). They were thallic, with schizolytic dehiscence, hyaline, cylindrical, smooth, measuring 6.612.7 $\times 3.6-4.6 \mu \mathrm{m}(\mathrm{x}=8.3 \times 4.0 \mu \mathrm{m}), \mathrm{D} / \mathrm{d}=1.81-3.46(\mathrm{x}=2.11)$, occasionally produced as subdivisions of the initial conidia and then having an aspect ratio $<=1.0$.

Although the growth rates of $L$. capsici and $L$. polypaeciloides do not appear to differ greatly between those grown at $7 \mathrm{C}$ and those at $22 \mathrm{C}$ there are quite noticeable differences as seen in Fig. 4. In the four isolates illustrated, colonies grown at $7 \mathrm{C}$ are larger and have more luxuriant aerial growth than those at $22 \mathrm{C}$. The one exception is L. capsici UAMH 11252, in the upper right quadrant, which, although slower, appears to have sporulated more abundantly.

Phylogenetic analysis.-The new DNA sequences determined for this study for each gene region are listed in Tables 5 and 6 with GenBank accession numbers. The isolates sampled included 15 from bats, three morphologically similar isolates, the type species of Leuconeurospora, and representatives of other genera hypothesized to be related based on current BLASTN searches and published phylogenies for those taxa. The ITS data matrix comprised 30 taxa and 529 characters of which 102 were parsimony informative. The RPB1 data matrix comprised 26 taxa and 698 characters of which 169 were parsimony informative. The RPB2 data matrix comprised 26 taxa and 1078 characters of which 283 were parsimony informative. Maximum parsimony analyses were conducted independently for each alignment, resulting in 2 most parsimonious trees (MPT) of score 184 (ITS), 77 MPT of score 543 (RPB1), and 9366 MPT of score 783 (RPB2). Bayesian analyses conducted independently resulted in a single consensus tree for each data matrix. One MPT for each gene is shown in Fig. 5A (ITS), Fig. 6A (RPB1) and Fig. 6B (RPB2).

Phylogenetic analyses of the individual data sets yielded trees of similar topologies in which all the bat isolates, the ex-type strains of Scopulariopsis capsici and Torula botryoides and L. pulcherrima (CBS 343.76), grouped with strong support (PP/BS $=96 / 100$ for ITS, 90/100 for RPB1 and 100/100 for RPB2) as a monophyletic clade distinct from the other taxa (Figs. 5, 6). Within the Leuconeurospora clade, two subclades distinct from the one representative of L. pulcherrima were strongly supported except in the ITS only analysis. The subclade designated Leuconeurospora capsici included the type strains for Scopulariopsis capsici and 
Torula botryoides (nomen illegitimum) and the ITS sequences were identical for all isolates except for UAMH 11458 which differed from all the others at one ITS2 position (417 in GenBank No. KJ55506, T instead of C). All isolates in the second subclade, designated L. polypaeciloides, had identical ITS sequences. Several strains within this subclade formed a Leuconeurospora teleomorph when paired in vitro. Relative to our 19 GenBank accessions for the genus, the ITS sequences of the two subclades differed at one ITS2 position (394) and both differed at two different positions from L. pulcherrima (116 and 452). The percent similarity among the three species for each gene, based on pairwise comparisons of data for one representative sequence from each subclade (UAMH 11251 and 11252) and for L. pulcherrima (CBS 343.76), was 99.4-99.8\% (ITS), 96.1-97.2\% (RPB1) and 96.9-97.3\% (RPB2). The pairwise distances calculated for each gene for all strains in the genus Leuconeuospora clearly identifies a distinct gap between the intra- and inter-specific levels for RPB1 and RPB2 but not for ITS (Fig. 5B).

\section{DISCUSSION}

Recent molecular phylogenetic studies (Minnis and Lindner 2013, Sogonov et al. 2005, Wang et al. 2006) have supported the classification of the "residual" Pseudeurotiaceae (sensu Suh and Blackwell 1999) in the Leotiomycetes with a relatively small number of cleistothecial ascomycete genera as members, including Leuconeurospora and the 5 genera represented in the DNA sequence analyses of this study. Most comprise small numbers of species based on Index Fungorum databases

(http://www.indexfungorum.org/names/Names.asp accessed January 26, 2015): Connersia (monotypic genus), Pleuroascus (6 species), Pseudeurotium (9 species), and the Pseudogymnoascus/Geomyces complex (approximately 15 species). The taxonomy database of NCBI currently lists records for many DNA sequences not identified to species under each of these genera (http://www.ncbi.nlm.nih.gov/Taxonomy/Browser/wwwtax.cgi?id=34379 accessed January 26, 2015), suggesting there is much diversity yet to be understood and evaluated for this lineage. Our multi-gene analyses provided strong support for the reclassification of Scopulariopsis capsici in Leuconeurospora and for the description of $L$. polypaeciloides as a new species (Malloch 2013). Our data do not support the transfer of S. capsici to the genus Aspergillus (family Trichocomaceae) as proposed by Samson et al. (2014). Both L. capsici and L. polypaeciloides have widespread distributions in bat hibernacula in New Brunswick, and it is likely that at least some of the unidentified sequences in $\mathrm{NCBI}$ are derived from representatives of these taxa. These species are not readily distinguished by ITS sequences alone since differences between them are few; however, more 
confident identifications could be made if in combination with morphological characters. In contrast, based on the sequences generated in this study, data for either of the protein coding genes would be diagnostic.

Leuconeurospora polypaeciloides differs notably from the type species L. pulcherrima in its conspicuous anamorph. Leuconeurospora pulcherrima was first isolated from rabbit and dog dung in Denmark by Emil Chr. Hansen (Hansen, 1876). Georg Winter found additional material on fox dung near Leipzig, Germany (Winter, 1887). It is not clear from either of those publications whether those authors ever saw the other's material. Significantly, Hansen stated that he could find no conidia. A culture from forest soil in Switzerland was deposited at the Centraalbureau voor Schimmelcultures, Utrecht, The Netherlands as CBS 343.76 (Table 5). This material, assumed to be conspecific with L. pulcherrima, was studied by Suh and Blackwell (1999) who made no mention of conidia. One of us (L.S.) followed the development of this isolate (UAMH $9397=$ CBS 343.76) over a period of five to seven months incubation at $9 \mathrm{C}$ and saw no evidence of an anamorph. These cultures produced sparse infertile cleistothecia, suggesting the species might also be heterothallic.

Malloch and Cain (1970) described and illustrated material from Ontario and Alberta, Canada, thought to represent $L$. pulcherrima. Unfortunately they were unable to obtain cultures from either of these collections and did not have the opportunity to observe their development. Because they were unable to comment on conidial development it is unclear now whether they had L. pucherrima, L. polypaeciloides or some other species. Ascospores of L. polypaeciloides and L. pulcherrima may differ slightly. Winter (1887) gave measurements of 5.0-6.5 X 4.0-5.0 $\mu \mathrm{m}$ for L. pulcherrima, differing from the 4.9-6.7 X 3.5-4.1 $\mu \mathrm{m}$ of L. polypaeciloides, especially in their widths. Malloch and Cain's more variable measurements of 5.5-7.0 X 3.5-5.0 $\mu \mathrm{m}$ in their collections suggest that the ascospores of the two species may not differ greatly.

Isolates of $L$. polypaeciloides were obtained from Howe's, Berryton and White Caves and from Markhamville and Glebe Mines, but never from Harbell's and Underground Lake Caves (Tables 2, 3). They were most abundant in Glebe Mine; not only on bats but also on flies, moths and spiders, and on the walls of the mine (Table 4). These additional isolates suggest that $L$. polypaeciloides was sporulating heavily in this mine and that its ascospores and/or conidia had become widely distributed. All sites yielding isolates of $L$. polypaeciloides showed evidence of vertebrates other than bats, particularly porcupines and raccoons. Porcupines have occupied Markhamville Mine and White Cave to the extent that there are large piles of feces on the floor. Although we have not yet studied the mycota of these piles we suspect that they will support L. polypaeciloides. Interestingly, the species of Leuconeurospora reported by Malloch and Cain (1970) was found abundantly on porcupine dung in an Ontario cave. 
The three caves not yielding isolates of $L$. polypaeciloides on bats were all quite wet. Harbell's and Kitt's Caves have streams running along their main passages while Underground Lake Cave, as its name implies, is dominated by a relatively large body of water (Table 1). While these streams and ponds seem not to significantly alter the relative humidity of the caves they occupy, they possibly discourage or prevent the entry of most nonflying vertebrates and their associated fungi. Kitt's Cave, however, yielded a single isolate of $L$. polypaeciloides from one of its walls (Table 4), suggesting that it may be only a less abundant component of the mycota in this cave. Kitt's Cave does have a beaver den, and McAlpine (1977) reported discovery of beaver scat in this cave.

Leuconeurospora capsici was less abundant on bats than L. polypaeciloides (Tables 2, 3). However it was isolated several times from Myotis spp. in Berryton Cave, the hibernaculum in this study yielding the highest count of bats. It may also be significant that $L$. capsici was also isolated from a bat in this cave that had been infected with $P$. destructans and had died.

Leuconeurospora capsici was long accepted as a member of the genus Polypaecilum. It is listed by many authorities under the name Polypaecilum botryoides (F.T. Brooks \& Handsf.) Vasant Rao \& de Hoog, a combination that cannot be maintained because its basionym, Torula botryoides F.T. Brooks \& Handsf., 1923 is a later homonym of $T$. botryoides Corda, 1829, an unrelated species. Houbraken and Samson (2011) showed the type of Polypaecilum, P. insolitum G. Sm., to be a member of the Aspergillaceae and therefore only very distantly related to Leuconeurospora, a member of the Pseudeurotiaceae (Suh and Blackwell, 1999).

Leuconeurospora capsici is easily distinguished from L. polypaeciloides by its dark greenish brown conidia with characteristically broad and somewhat flattened apices. It is the only one of the three described species of Leuconeurospora not known to produce ascomata.

Recent surveys of bat hibernacula have yielded a diversity of fungi, many of which are psychrotolerant (Minnis and Lindner 2013, Vanderwolf et al. 2013a,b). The two Leuconeurospora species reported here grew well at the low temperatures found in the caves (averaging $6.0 \pm 1.3 \mathrm{C}$ and ranging from $2.6-14.1 \mathrm{C}$ ) and in culture at $7 \mathrm{C}$ and $22 \mathrm{C}$. Our isolates were not tested at lower or higher temperatures because the study was focused more on tolerance to the low temperatures found in the hiberacula. Further evidence of psychrotolerance comes from the isolation of Leuconeurospora species from food in cold storage and from Antarctica (Table 5; Kochkina et al. 2014). Interestingly, the isolates of Leuconeurospora reported by Lorch et al. (2013) and Minnis and Lorch (2013) appear to represent species different from those reported here. A BLAST search of their RPB2 sequences did not yield matches to either L. capsici or L. polypaeciloides while their ITS sequences appear to show their isolates to be in a separate clade within the Leuconeurospora clade. These 
results suggest that there may be additional species of this interesting genus of cave-inhabiting fungi.

\section{ACKNOWLEGEMENTS}

Funding for this work was provided by the Canadian Wildlife Federation, New Brunswick Wildlife Trust Fund, New Brunswick Environmental Trust Fund, New Brunswick Department of Natural Resources, Parks Canada, and the National Speleological Society White-nose Rapid Response Fund. We offer our particular thanks to Dr. Graham Forbes, University of New Brunswick, for his assistance in the field and his support and encouragement to KJV. We thank C.A. Lévesque and Q. Eggertson for help with the data analyses in $R$ and Linux.

\section{LITERATURE CITED}

Bills, G.F. and Foster, M.S. 2004. Formulae for selected materials used to isolate and study fungi and fungal allies. In Biodiversity of fungi: inventory and monitoring methods. Edited by G.M. Mueller, G.F. Bills, and M.S. Foster. Elsevier, Amsterdam pp 595-635.

Darriba, D., Taboada, G.L., Doallo, R. and Posada, D. 2012. jModelTest 2: more models, new heuristics and parallel computing. Nature Methods 9, 772. doi:10.1038/nmeth.2109

Gibas, C.F.C., Sigler, L., Summerbell, R.C., Hofstader, S.L.R., and Gupta, A.K. 2002. Arachnomyces kanei (anamorph Onychocola kanei) sp. nov., from human nails. Med. Mycol. 40: 573-580. doi:10.1080/714031153.

Hansen, E.C. 1876. De danske gjødningesvampe (fungi fimicoli danici). B. Lunos bogtrykkori, Kjøbenhavn. pp 207-354 + PI. IV-IX.

Hawksworth, D.L., Kirk, P.M., Sutton, B.C., and Pegler, D.N. 1995. Ainsworth and Bisby's Dictionary of the Fungi. CAB International, Wallingford i-xii + 616 p.

Houbraken, J., and Samson, R.A. 2011. Phylogeny of Penicillium and the segregation of the Trichocomaceae into three families. Stud. Mycol. 70: 1-51. doi:10.3114/sim.2011.70.01.

Katoh, K., and Toh, H. 2008. Improved accuracy of multiple ncRNA alignment by incorporating structural information into a MAFFT-based framework. BMC Bioinformatics 9: 212. doi: 10.1186/1471-2105-9-212. 
Katoh, K., Asimenos, G., and Toh, H. 2009. Multiple alignment of DNA sequences with MAFFT. In Bioinformatics for DNA Sequence Analysis. Edited by D. Posada. Humana Press, Totowa, NJ pp 39-64.

Kochkina, G.A., Ozerskaya, N.E., Ivanushkina, N.E., Chigineva, N.I., Vasilenko, O.V., Spirina, E.V. and Gilichinskii, D.A. 2014. Fungal diversity in the Antarctic active layer. Microbiology 83: 94-101. DOI: $10.1134 / \mathrm{S} 002626171402012 \mathrm{X}$

Kornerup, A., and Wanscher, J.H. 1978. Methuen Handbook of Colour. Eyre Methuen, London 252 p.

Liu, Y.J., Whelen, S., and Hall, B.D. 1999. Phylogenetic relationships among ascomycetes: evidence from an RNA polymerase II subunit. Mol. Biol. Evol. 16: 1799-1808. doi:10.1093/oxfordjournals.molbev.a026092.

Lorch, J.M., Lindner,D.L., Gargas, A., Muller, L.K., Minnis, A.M., and Blehert, D.S. 2013. A culture-based survery of fungi in soil from bat hibernacula in the eastern United States and its implications for detection of Geomyces destructans, the causal agent of bat white-nose syndrome. Mycologia 105: 237-252. doi: 10.3852/12-207.

Malloch, D. 2013. Nomenclatural novelties. Index Fungorum 20: 1.

Malloch, D. and Cain, R.F. 1970. Five new genera in the new family Pseudeurotiaceae. Can. J. Bot. 48: 18151825.

McAlpine, D.F. 1977. Notes on cave utilization by beaver. Bull. Natl. Speleol. Soc. 39: 90-91. doi: 10.2307/1380608.

Minnis, A.M. and Lindner, D.L. 2013. Phylogenetic evaluation of Geomyces and allies reveals no close relatives of Pseudogymnoascus destructans, comb. nov., in bat hibernacula in eastern North America. Fungal Biol. 117: 638-649. doi:10.1016/j.funbio.2013.07.001.

Papavizas, G.C. and Davey, C.B. 1959. Evaluation of various media and antimicrobial agents for isolation of soil 
fungi. Soil Science 88: 112-117.

Paradis, E., Claude, J., and Strimmer, K. 2004. APE: analyses of phylogenetics and evolution in R language. Bioinformatics 20: 289-290.

R Core Team. 2014. R: A language and environment for statistical computing. R Foundation for Statistical Computing, Vienna, Austria. http://www.Rproject.org/.

Samson, R.A., Visagie, C.M., Houbraken, J., Hong, S.-B., Hubka, V., Klaassen, C.H.W.,Perrone, G., Seifert, K.A., Susca, A., Tanney, J.B., Varga, J., Kocsube, Szigeti, G., Yaguchi, T. and Frisvad, J.C. 2014. Phylogeny, identification and nomenclature of the genus Aspergillus. Stud. Mycol. 78: 141-173.

Sogonov, M.V., Schroers, H-J., Gams, W., Dijksterhius, J. and Summerbell, R.C. 2005. The hyphomycete Teberdinia hygrophila gen. nov., sp. nov. and related anamorphs of Pseudeurotium species. Mycologia 97: 695709.

Suh, S.-O., Blackwell, M. (1999) Molecular phylogeny of the cleistothecial fungi placed in Cephalothecaceae and Pseudeurotiaceae. Mycologia 91:836-848.

Tang, A.M.C., J.R. and Hyde, K.D. 2009. A re-evaluation of the evolutionary relationships within the Xylariaceae based on ribosomal and protein-coding gene sequences. Fungal Diversity 34:127-155.

Vanderwolf, K.J., McAlpine, D.F., Forbes, G.J. and Malloch, D. 2012. Bat populations and cave microclimate prior to and at the outbreak of white-nose syndrome in New Brunswick. Can Field Nat 126: 125-134.

Vanderwolf, K.J., Malloch, D., McAlpine, D.F. and Forbes, G.J. (2013a) A world review of fungi, yeasts and slime molds in caves. Int. J. Speleol. 42: 77-96. http://dx.doi.org/10.5038/1827-806X.42.1.9

Vanderwolf, K.J., McAlpine, D.F., Malloch, D. and Forbes, G.J. 2013b. Ectomycota associated with hibernating 
cave bats in eastern Canada prior to the emergence of white-nose syndrome. Northeast Nat 20: 115-130. doi: http://dx.doi.org/10.1656/045.020.0109

Wang, Z., Johnston, P.R., Takamatsu, S., Spatafora, J.W. and Hibbett, D.S. 2006. Toward a phylogenetic classification of the Leotiomycetes based on rDNA data. Mycologia 98: 1065-1075.

doi:10.3852/mycologia.98.6.1065

White, T.J., Bruns, T.D., Lee. S. and Taylor, J.W. 1990. Amplification and direct sequencing of fungal ribosomal RNA genes for phylogenetics. In PCR Protocols: a guide to methods and applications. Edited by Innis, M.A., Gelfand, D.H., Sninsky, J.J. and White, T.J. Academic Press, San Diego pp 315-322.

Wickham, W. 2009. ggplot2: Elegant graphics for data analysis. Springer New York.

Winter, G. 1887. Die Pilze 1(2): Gymnoasceen und Pyrenomyceten. In: Dr. L Rabenhorst's Kryptogamen-Flora von Deutschland, Oesterreich und der Schweiz. Eduard Kummer Verl, Leipzig

Zhang, T., Victor, T.R., Rajkumar, S.S., Li, X., Okoniewski, J.C., Hicks, A.C., Davis, A.D., Broussard, K., LaDeau, S.L., Chaturvedi, S. and Chaturvedi, V. 2014. Mycobiome of the bat white nose syndrome affected caves and mines reveals diversity of fungi and local adaptation by the fungal pathogen Pseudogymnoascus (Geomyces) destructans. PLoS One. 29:9(9):e108714. doi: 10.1371/journal.pone.0108714. eCollection 2014. Erratum in: PLoS One. 2014:9(12):e116149. 
Table 1. Sites of caves and mines sampled in New Brunswick, Canada.

\begin{tabular}{llll}
\hline Site name (abbreviation) & Nearest town & Geology & $\begin{array}{l}\text { Presence of } \\
\text { significant } \\
\text { water body }\end{array}$ \\
\hline Berryton Cave (Be) & Berryton & Limestone & No \\
Dalling's Cave (Da) & Waterford & Limestone & Yes \\
Dorchester Mine (Do) & Dorchester & Copper mine & Yes \\
Glebe Mine (Gl) & Waterford & Manganese mine & No \\
Harbell's Cave (Ha) & Saint John & Limestone & Yes \\
Howe's Cave (Ho) & Saint John & Limestone & No \\
Kitts Cave (Ki) & Hammondvale & Limestone & Yes \\
Markhamville Mine (Ma) & Markhamville & Manganese mine & No \\
Underground Lake Cave (Un) & Albert Mines & Gypsum & Yes \\
White Cave (Wh) & Hillsborough & Gypsum & No \\
\hline
\end{tabular}


Table 2. Leuconeurospora species isolated from surface swabs of 10 bats (Myotis lucifugus, M. septentrionalis) from eight sites.

\begin{tabular}{|c|c|c|c|c|c|c|c|c|c|}
\hline \multirow[b]{2}{*}{2010} & \multicolumn{8}{|c|}{ Site $^{a}$} & \multirow[b]{2}{*}{ TOTAL } \\
\hline & $\mathrm{Be}$ & Gl & $\mathrm{Ha}$ & Ho & $\mathrm{Ki}$ & $\mathrm{Ma}$ & Un & $\mathrm{Wh}$ & \\
\hline L. capsici & $3^{b}$ & 0 & 0 & 0 & 0 & 1 & 0 & 1 & $5 / 80$ \\
\hline L. polypaeciloides & 3 & 5 & 0 & 2 & 0 & 10 & 0 & 8 & $28 / 80$ \\
\hline \multicolumn{10}{|l|}{2012} \\
\hline L. capsici & 7 & $\mathrm{~ns}^{c}$ & 0 & 0 & ns & 1 & $\mathrm{~ns}$ & 1 & $9 / 50$ \\
\hline L. polypaeciloides & 1 & ns & 0 & 0 & ns & 6 & ns & 3 & $10 / 50$ \\
\hline
\end{tabular}

${ }^{a}$ Site names according to Table 1 .

${ }^{b}$ Number of bats yielding isolates.

${ }^{c}$ Not sampled due to lack of bats. 
Table 3. Leuconeurospora species isolated from surface swabs of Perimyotis subflavus.

\begin{tabular}{|c|c|c|c|c|c|c|c|c|c|c|}
\hline \multirow{3}{*}{2012} & \multicolumn{9}{|c|}{ Site $^{a}$ and number of bats sampled } & \multirow{3}{*}{$\begin{array}{c}\text { TOTAL } \\
\text { (15) }\end{array}$} \\
\hline & $\mathrm{Be}$ & $\mathrm{Da}$ & Gl & $\mathrm{Ha}$ & Ho & $\mathrm{Ki}$ & $\mathrm{Ma}$ & Un & Wh & \\
\hline & $\left(0^{b}\right)$ & $(0)$ & (7) & (1) & $(0)$ & $(0)$ & (7) & $(0)$ & $(0)$ & \\
\hline L. capsici & $\mathrm{nd}^{c}$ & nd & 0 & 0 & nd & nd & $1^{d}$ & nd & nd & $1 / 15$ \\
\hline L. polypaeciloides & nd & nd & 6 & 0 & nd & nd & 2 & nd & nd & $8 / 15$ \\
\hline 2013 & $(0)$ & (1) & $(2)$ & $(0)$ & $(0)$ & $(0)$ & $(3)$ & $(0)$ & $(0)$ & $(6)$ \\
\hline L. capsici & nd & 0 & 0 & nd & nd & nd & 0 & nd & nd & $0 / 6$ \\
\hline L. polypaeciloides & nd & 0 & 2 & nd & nd & nd & 3 & nd & nd & $5 / 6$ \\
\hline
\end{tabular}

${ }^{a}$ Site names according to Table 1 .

${ }^{b}$ No Perimyotis subflavus present.

${ }^{c}$ No data.

${ }^{d}$ Number of bats yielding isolates. 
Table 4. Leuconeurospora species isolated from substrata including cave walls and arthropods.

\begin{tabular}{|c|c|c|c|c|c|c|c|c|c|c|c|}
\hline \multirow[b]{2}{*}{2012} & \multicolumn{11}{|c|}{ Site $^{a}$ and substrates ${ }^{b}$ sampled } \\
\hline & $\begin{array}{c}\mathrm{Be} \\
\left(\mathrm{w} / 12^{c}\right)\end{array}$ & $\begin{array}{c}\mathrm{Be} \\
(\mathrm{d} / 1)\end{array}$ & $\begin{array}{c}\text { Gl } \\
\text { (f/6) }\end{array}$ & $\begin{array}{c}\mathrm{Gl} \\
(\mathrm{m} / 3)\end{array}$ & $\begin{array}{c}\text { G1 } \\
(\mathrm{s} / 3)\end{array}$ & $\begin{array}{c}\mathrm{Gl} \\
(\mathrm{w} / 10)\end{array}$ & $\begin{array}{l}\text { Do } \\
\text { (f/7) }\end{array}$ & $\begin{array}{c}\text { Do } \\
(\mathrm{m} / 2)\end{array}$ & $\begin{array}{l}\text { Do } \\
(\mathrm{s} / 3)\end{array}$ & $\begin{array}{c}\text { Do } \\
(w / 10)\end{array}$ & $\begin{array}{l}\text { Total } \\
(57)\end{array}$ \\
\hline L. capsici & $6^{d}$ & 1 & 0 & 0 & 0 & 0 & 0 & 0 & 0 & 0 & $7 / 57$ \\
\hline L. polypaeciloides & 0 & 0 & 5 & 1 & 3 & 6 & 1 & 0 & 0 & 0 & $16 / 57$ \\
\hline 2013 & $\begin{array}{c}\mathrm{Gl} \\
(\mathrm{s} / 2)\end{array}$ & $\begin{array}{c}\mathrm{Gl} \\
(\mathrm{h} / 2)\end{array}$ & $\begin{array}{c}\mathrm{Ki} \\
(\mathrm{w} / 7)\end{array}$ & $\begin{array}{c}\mathrm{Ma} \\
(\mathrm{m} / 2)\end{array}$ & $\begin{array}{l}\mathrm{Ma} \\
(\mathrm{h} / 1)\end{array}$ & $\begin{array}{l}\mathrm{Da} \\
(\mathrm{m} / 4)\end{array}$ & $\begin{array}{l}\text { Do } \\
(\mathrm{h} / 6)\end{array}$ & $\begin{array}{c}\text { Do } \\
(\mathrm{m} / 1)\end{array}$ & $\begin{array}{l}\text { Do } \\
(\mathrm{s} / 4)\end{array}$ & & $\begin{array}{l}\text { Total } \\
(29)\end{array}$ \\
\hline L. capsici & 0 & 0 & 0 & 0 & 0 & 1 & 0 & 0 & 0 & & $1 / 29$ \\
\hline L. polypaeciloides & 1 & 2 & 1 & 1 & 1 & 0 & 1 & 0 & 1 & & $8 / 29$ \\
\hline
\end{tabular}

${ }^{a}$ Site names according to Table 1. Note that the sites sampled in 2012 and 2013 differ.

${ }^{b}$ Substrates: $\mathrm{d}=$ cadaver of Myotis lucifugus, $\mathrm{f}=\mathrm{fly}$ (Exechiopsis $\left.\mathrm{sp}.\right), \mathrm{h}=$ harvestman (Nelima elegans), $\mathrm{m}=$ moth (Scoliopteryx libatrix), $\mathrm{s}=\operatorname{spider}$ (Meta ovalis), w=cave wall.

${ }^{c}$ Number of samples taken per substrate.

${ }^{d}$ Number of Leuconeurospora isolates obtained from the substrate. 
Table 5. Leuconeurospora isolates examined in this study.

\begin{tabular}{|c|c|c|c|c|c|c|c|c|c|}
\hline \multirow[b]{2}{*}{$\begin{array}{l}\text { UAMH } \\
\text { No. }^{a}\end{array}$} & \multicolumn{5}{|c|}{ GenBank No. $^{d}$} & \multirow[b]{2}{*}{ Substrate } & \multirow[b]{2}{*}{ Isolator(s) } & \multirow[b]{2}{*}{ Year } & \multirow[b]{2}{*}{ Other data } \\
\hline & Other No. & ITS & RPB1 & RPB2 & Location & & & & \\
\hline \multicolumn{10}{|c|}{ Leuconeurospora capsici } \\
\hline 935 & CBS 176.44 & KJ755509 & $\begin{array}{l}\text { KJ75545 } \\
7\end{array}$ & KJ755483 & Netherlands & $\begin{array}{l}\text { Capsicum annuum } \\
\text { "De Körver" }\end{array}$ & $\begin{array}{l}\text { F.H. van } \\
\text { Beyma }\end{array}$ & & $\begin{array}{l}\text { Type: Scopulariopsis } \\
\text { capsici }\end{array}$ \\
\hline 11121 & & KJ755501 & $\begin{array}{l}\text { KJ75544 } \\
9\end{array}$ & KJ755475 & $U n^{b}$ & skin, bat & $\mathrm{KJV} \& \mathrm{DFM}^{c}$ & 2009 & \\
\hline 11248 & NBM F-03666 & KJ755502 & $\begin{array}{l}\text { KJ75545 } \\
0\end{array}$ & KJ755476 & Wh & $\begin{array}{l}\text { fur, female Myotis } \\
\text { lucifugus }\end{array}$ & KJV \& DFM & 2010 & \\
\hline 11249 & NBM F-03622 & KJ755503 & $\begin{array}{l}\text { KJ75545 } \\
1\end{array}$ & KJ755477 & $\mathrm{Be}$ & $\begin{array}{l}\text { fur, female Myotis } \\
\text { lucifugus }\end{array}$ & KJV \& DFM & 2010 & \\
\hline 11252 & CBS 143.23 & KJ755504 & $\begin{array}{l}\text { KJ75545 } \\
2\end{array}$ & KJ755478 & England & $\begin{array}{l}\text { halibut in cold } \\
\text { storage }\end{array}$ & $\begin{array}{l}\text { F.T. Brooks } \\
\text { \& C.G. } \\
\text { Hansford }\end{array}$ & 1918 & $\begin{array}{l}\text { Type: Torula } \\
\text { botryoides }\end{array}$ \\
\hline 11253 & CBS 122042 & KJ755505 & $\begin{array}{l}\text { KJ75545 } \\
3\end{array}$ & KJ755479 & Antarctica & soil, Antarctica & $\begin{array}{l}\text { A.M. Stchigel } \\
\& \text { W.P. } \\
\text { MacCormack }\end{array}$ & 1996 & $\begin{array}{l}\text { Polypaecilum } \\
\text { antarcticum (unpubl) }\end{array}$ \\
\hline 11458 & NBM F-03526 & KJ755506 & $\begin{array}{l}\text { KJ75545 } \\
4\end{array}$ & KJ755480 & $\mathrm{Ma}$ & $\begin{array}{l}\text { fur, male Myotis } \\
\text { lucifugus }\end{array}$ & KJV \& DFM & 2010 & \\
\hline 11460 & NBM F-04960 & KJ755507 & $\begin{array}{l}\text { KJ75545 } \\
5\end{array}$ & KJ755481 & $\mathrm{Be}$ & $\begin{array}{l}\text { skin, male Myotis } \\
\text { lucifugus }\end{array}$ & KJV \& DFM & 2010 & \\
\hline 11463 & NBM F-04959 & KJ755508 & $\begin{array}{l}\text { KJ75545 } \\
6\end{array}$ & KJ755482 & $\mathrm{Be}$ & $\begin{array}{l}\text { fur, male Myotis } \\
\text { lucifugus }\end{array}$ & KJV \& DFM & 2010 & \\
\hline 11721 & NBM F-04948 & $\mathrm{nd}^{d}$ & nd & nd & $\mathrm{Be}$ & fur, Myotis lucifugus & KJV \& DFM & 2012 & \\
\hline 11722 & & nd & nd & nd & $\mathrm{Be}$ & cave wall & KJV \& DFM & 2012 & \\
\hline \multicolumn{10}{|c|}{ Leuconeurospora polypaeciloides } \\
\hline 11250 & NBM F-03557 & KJ755510 & $\begin{array}{l}\text { KJ75545 } \\
8\end{array}$ & KJ755484 & $\mathrm{Gl}$ & $\begin{array}{l}\text { skin, female Myotis } \\
\text { lucifugus }\end{array}$ & KJV \& DFM & 2010 & - mating strain \\
\hline 11251 & NBM F-04962 & KC884265 & $\begin{array}{l}\text { KJ75545 } \\
9\end{array}$ & KJ755485 & Wh & $\begin{array}{l}\text { fur, male Myotis } \\
\text { lucifugus }\end{array}$ & KJV \& DFM & 2010 & - mating type strain \\
\hline 11459 & & KC884266 & $\begin{array}{l}\text { KJ75546 } \\
0\end{array}$ & KJ755486 & $\mathrm{Ma}$ & $\begin{array}{l}\text { skin, female Myotis } \\
\text { lucifugus }\end{array}$ & KJV \& DFM & 2010 & + mating type strain \\
\hline 11461 & & KJ755512 & $\begin{array}{l}\text { KJ75546 } \\
1\end{array}$ & KJ755487 & Wh & $\begin{array}{l}\text { skin, Pipistrellus } \\
\text { subflavus }\end{array}$ & KJV \& DFM & 2010 & \\
\hline 11504 & NBM F-04957 & KJ755513 & $\begin{array}{l}\text { KJ75546 } \\
2\end{array}$ & KJ755488 & $\mathrm{Ma}$ & $\begin{array}{l}\text { fur, male Myotis } \\
\text { lucifugus }\end{array}$ & KJV \& DFM & 2010 & - mating strain \\
\hline 11512 & NBM F-04953 & KJ755514 & $\begin{array}{l}\text { KJ75546 } \\
3\end{array}$ & KJ755489 & Ho & $\begin{array}{l}\text { fur, male Myotis } \\
\text { septentrionalis }\end{array}$ & KJV \& DFM & 2010 & \\
\hline 11513 & NBM F-04954 & KJ755515 & $\begin{array}{l}\text { KJ75546 } \\
4\end{array}$ & KJ755490 & Ma & $\begin{array}{l}\text { fur, male Myotis } \\
\text { septentrionalis }\end{array}$ & KJV \& DFM & 2010 & - mating strain \\
\hline 11622 & NBM F-04956 & KJ755516 & nd & nd & $\mathrm{Ma}$ & $\begin{array}{l}\text { skin, male Myotis } \\
\text { lucifugus }\end{array}$ & KJV \& DFM & 2010 & + mating strain \\
\hline
\end{tabular}




\begin{tabular}{|c|c|c|c|c|c|c|c|c|}
\hline 11639 & NBM F-04952 & KJ755517 & nd & nd & Wh & $\begin{array}{l}\text { skin, male Myotis } \\
\text { lucifugus }\end{array}$ & KJV \& DFM & $2010+$ mating strain \\
\hline 11723 & & nd & nd & nd & Wh & fur, Myotis lucifugus & KJV \& DFM & 2012 \\
\hline 11724 & & nd & nd & nd & Wh & $\begin{array}{l}\text { skin, Myotis } \\
\text { lucifugus }\end{array}$ & KJV \& DFM & 2012 \\
\hline 11725 & & nd & nd & nd & $\mathrm{Ma}$ & $\begin{array}{l}\text { fur, Perimyotis } \\
\text { subflavus }\end{array}$ & KJV \& DFM & 2012 \\
\hline 11726 & & nd & nd & nd & $\mathrm{Gl}$ & $\begin{array}{l}\text { herald moth, } \\
\text { Scolipteryx libatrix }\end{array}$ & KJV \& DFM & 2012 \\
\hline 11727 & & nd & nd & nd & Do & fly, Exechiopsis sp. & KJV \& DFM & 2012 \\
\hline 11728 & & nd & nd & nd & $\mathrm{GI}$ & $\begin{array}{l}\text { cave orb weaver, } \\
\text { Meta ovalis }\end{array}$ & KJV \& DFM & 2012 \\
\hline 11729 & & nd & nd & nd & GI & cave wall & KJV \& DFM & 2012 \\
\hline 11730 & & nd & nd & nd & $\mathrm{Ma}$ & $\begin{array}{l}\text { fur, Perimyotis } \\
\text { subflavus }\end{array}$ & KJV \& DFM & 2012 \\
\hline \multicolumn{9}{|c|}{ Leuconeurospora pulcherrima } \\
\hline 9397 & CBS 343.76 & KJ755518 & $\begin{array}{l}\text { KJ75546 } \\
5\end{array}$ & KJ755491 & Switzerland & forest soil & E. Müller & \\
\hline
\end{tabular}

${ }^{a}$ Collection acronyms: CBS - Centraalbureau voor Schimmelcultures, Utrecht, Netherlands; NBM - New Brunswick Museum,

Saint John, NB, Canada; UAMH - UAMH Centre for Global Microfungal Biodiversity, University of Toronto, Toronto, ON,

Canada [formerly University of Alberta Microfungus Collection and Herbarium].

${ }^{b}$ Collection site abbreviations according to Table 1.

${ }^{c}$ KJV -- K.J. Vanderwolf; DFM - D.F. McAlpine

${ }^{d}$ nd $=$ not sequenced

Table 6. Additional strains used for phylogenetic analysis.

\begin{tabular}{llllll}
\hline & & \multicolumn{2}{l}{ GenBank No. } & \\
\cline { 3 - 5 } Name & Accession No. (Other No.) & ITS & RPB1 & RPB2 & Provenance (Type Status) \\
\hline Connersia rilstonii & CBS 537.74 (DAOM 145387) & KJ755499 & KJ755447 & KJ755473 & Ontario, Canada \\
Geomyces asperulatus & UAMH 183 (DAOM 231159) & KJ755500 & KJ755448 & KJ755474 & Massachusetts, USA (Type) \\
Pleuroascus nicholsonii & CBS 345.73 & KJ755519 & nd & nd & California, USA (Neotype)
\end{tabular}


Pseudeurotium hygrophilum

Pseudeurotium ovale var. ovale

Pseudeurotium zonatum

Pseudeurotium zonatum

Pseudogymnoascus appendiculatus

Pseudogymnoascus roseus

Pseudogymnoascus verrucosus

Pseudogymnoascus sp.

Pseudogymnoascus sp.

$\begin{array}{lccc}\text { UAMH } 11527 \text { (CBS 102670) } & \text { KJ755520 } & \text { KJ755466 } & \text { KJ755492 } \\ \text { UAMH 5825 } & \text { KJ755521 } & \text { nd } & \text { nd } \\ \text { ATCC 62440 (CBS 480.86) } & \text { nd } & \text { nd } & \text { KJ755493 } \\ \text { CBS 329.36 } & \text { KJ755522 } & \text { KJ755467 } & \text { KJ755494 } \\ \text { UAMH 10509 } & \text { KJ755523 } & \text { KJ755468 } & \text { nd } \\ \text { UAMH 1990 } & \text { KJ755524 } & \text { KJ755469 } & \text { KJ755495 } \\ \text { UAMH 10579 } & \text { KJ755525 } & \text { KJ755470 } & \text { KJ755496 } \\ \text { UAMH 875 } & \text { KJ755526 } & \text { KJ755471 } & \text { KJ755497 } \\ \text { UAMH 5339 (CBS 388.68) } & \text { KJ755527 } & \text { KJ755472 } & \text { KJ755498 }\end{array}$

Karachai-Cherkess Republic, Russia (Type)

Province De Liége, Belgium

Newfoundland, Canada

Versailles, France (Type)

Alberta, Canada (Type)

Wisconsin, USA

Alberta, Canada (Type)

West Ongul Is., Antarctica (Type:

Chrysosporium verrucosum)

Netherlands (Type: Chrysosporium merdarium var. roseum)

${ }^{a}$ Collection acronyms: ATCC - American Type Culture Collection, Manassas, Virginia; USA; CBS - Centraalbureau voor Schimmelcultures,

Utrecht, Netherlands; DAOM - National Mycological Herbarium, Ottawa, Ontario, Canada; UAMH - UAMH Centre for Global Microfungal

Biodiversity, University of Toronto, Toronto, ON, Canada.

${ }^{b}$ nd $=$ not sequenced 


\section{LEGENDS}

Fig. 1. Leuconeurospora capisici UAMH 11460, conidiogenesis.

Fig. 2. Leuconeurospora polypaeciloides Vanderwolf 43SOc2, conidiogenesis.

Fig. 3. Leuconeurospora polypaeciloides UAMH 11459x11504, teleomorph and arthroconidia. (A) Cleistothecial peridium.

(B) Asci. (C) Ascogenous hyphae. (D) Arthroconidia. (E) Ascospores. A: scale bar $=50 \mu \mathrm{m}$, B-E: scale bar $=10 \mu \mathrm{m}$.

Fig. 4. Colonies of Leuconeurospora spp. In $9 \mathrm{~cm}$ Petri dishes containing DPYA and MEA after 3 weeks. Top pair of each quadrant on DPYA at $7 \mathrm{C}$ (left) and $22 \mathrm{C}$ (right); bottom pair on MEA at $7 \mathrm{C}$ (left) and $22 \mathrm{C}$ (right). (A) L. polypaeciloides UAMH 11251. (B) L. polypaeciloides UAMH 11459. (C) L. capsici UAMH 11252. (D) L. capsici UAMH 11460.

Fig. 5. Phylogenetic relationships of three Leuconeurospora species and other members of the Pseudeurotiaceae inferred from parsimony analyses of ITS DNA sequences, and pairwise distances calculated for the genus Leuconeurospora for ITS, $R P B 1$ and $R P B 2$. (A) One of 2 equally parsimonious trees inferred from parsimony analyses of ITS DNA sequences.

Posterior probability values of $\geq 85 \%$ followed by bootstrap values of $\geq 75 \%$ and are shown above or beside the branches. $T$ indicates an ex-type culture. For L. polypaeciloides, MT (mating type) or M (mating) indicates a positive (+) or negative (-) strain; the holotype was derived from pairing MT strains UAMH 11251 and UAMH 11459. (B) Distribution of intra- and inter-specific pairwise distances for all strains in the genus Leuconeurospora, for each gene region analyzed in this study. The average distance is represented by the dotted lines.

Fig. 6. Phylogenetic relationships of three Leuconeurospora species and other members of the Pseudeurotiaceae inferred from parsimony analyses of (A) RPB1 and (B) RPB2 DNA sequences, showing one of 77 and 9,366 equally parsimonious trees, respectively. Posterior probability values of $\geq 85 \%$ followed by bootstrap values of $\geq 75 \%$ and are shown above or beside the branches (the values internal to the $L$. capsici clade were omitted due to space limitations). T indicates an ex-type culture. For L. polypaeciloides, MT (mating type) or M (mating) indicates a positive $(+)$ or negative $(-)$ strain; the holotype was derived from pairing MT strains UAMH 11251 and UAMH 11459. 


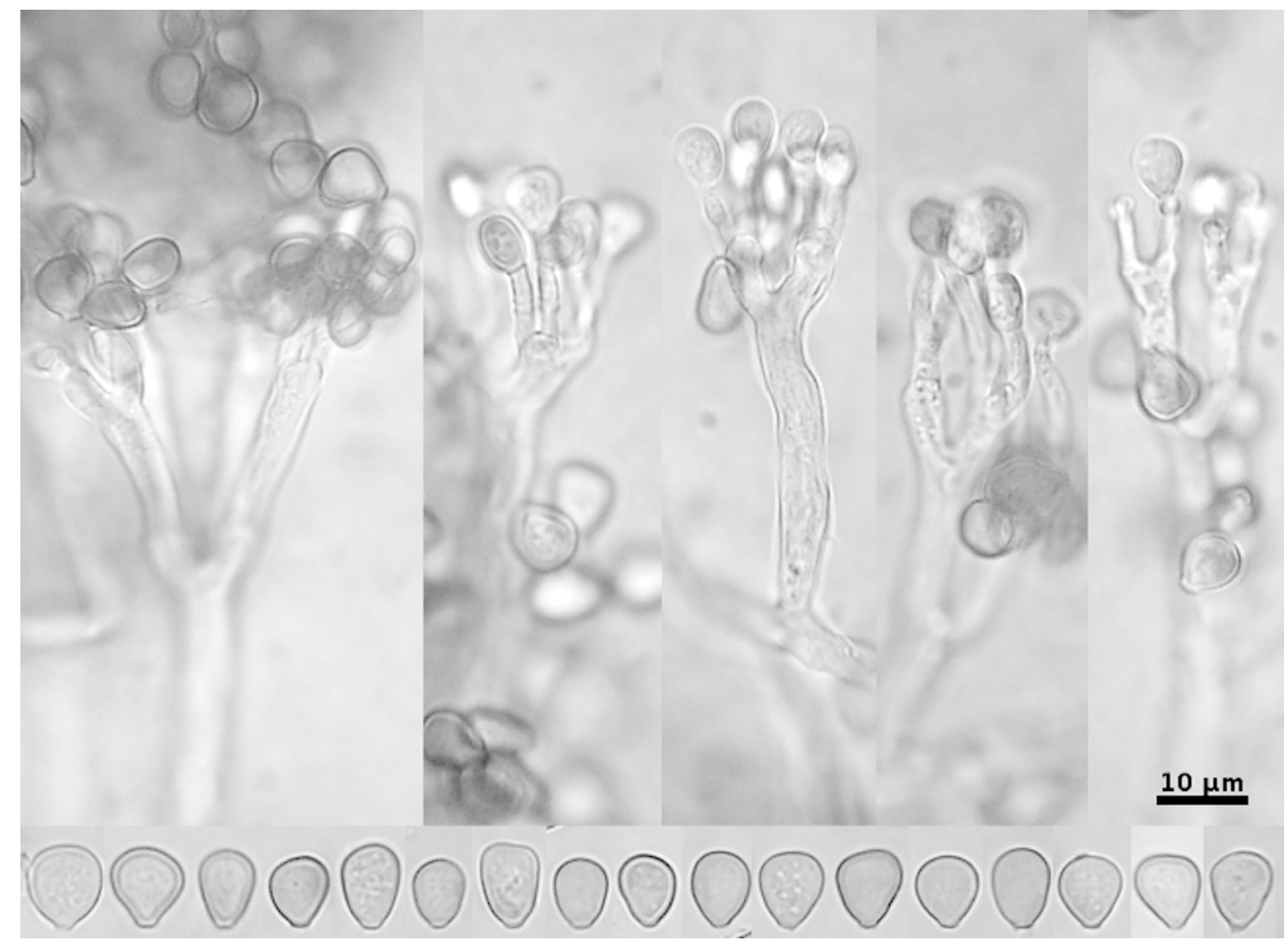

$182 \times 133 \mathrm{~mm}(300 \times 300 \mathrm{DPI})$ 


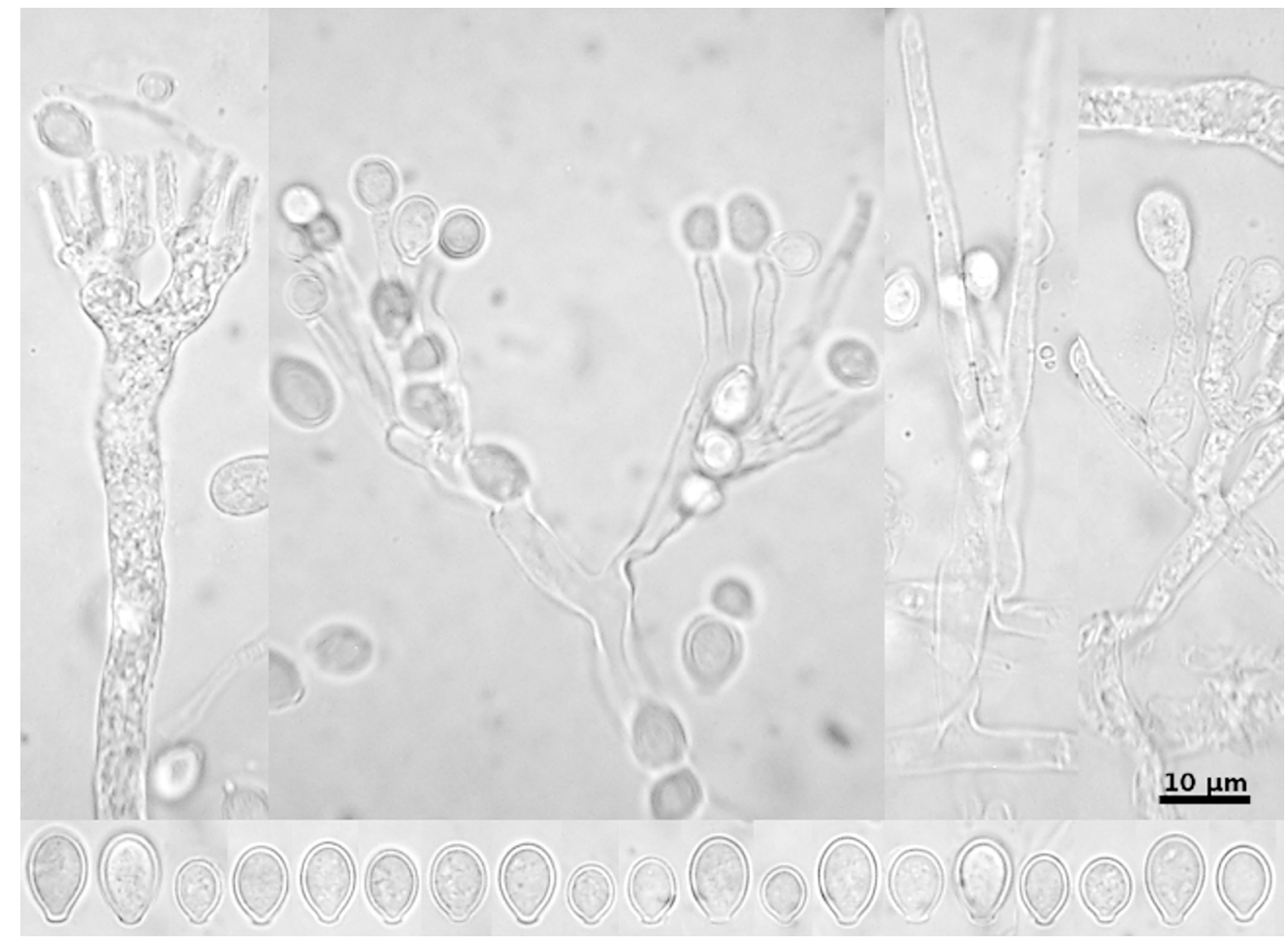

$182 \times 133 \mathrm{~mm}(300 \times 300$ DPI $)$ 


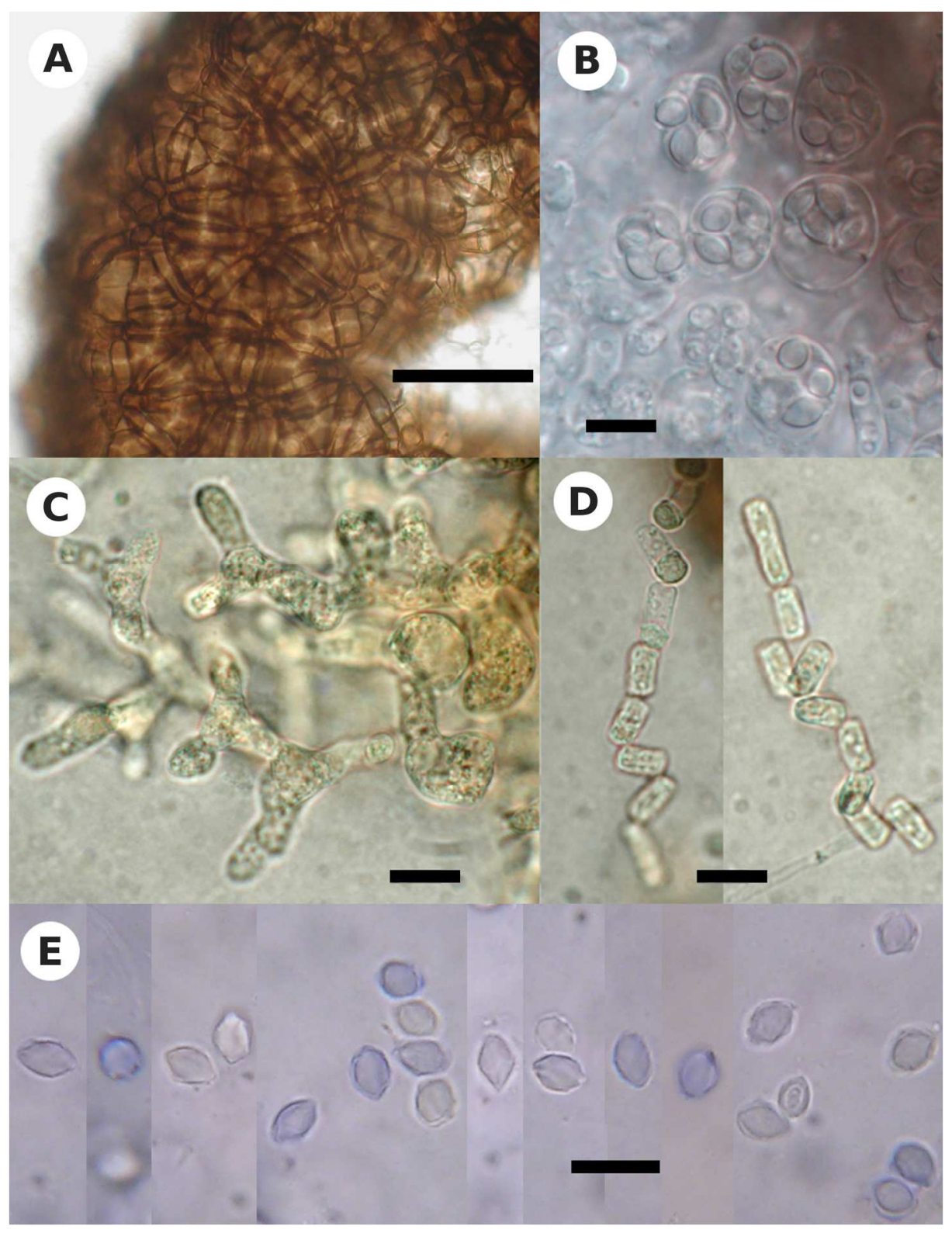

$182 \times 236 \mathrm{~mm}(300 \times 300 \mathrm{DPI})$ 

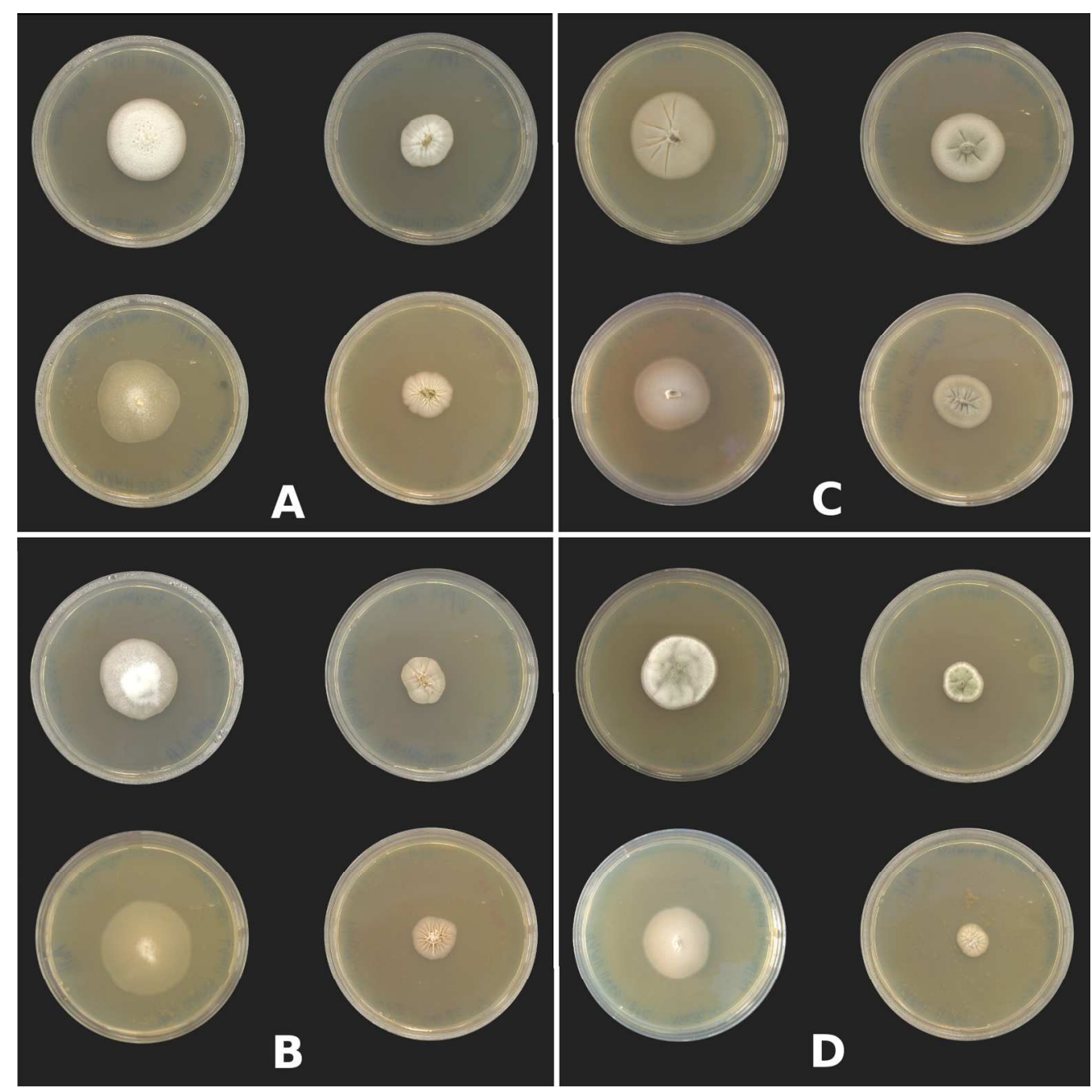

$182 \times 182 \mathrm{~mm}(300 \times 300$ DPI $)$ 


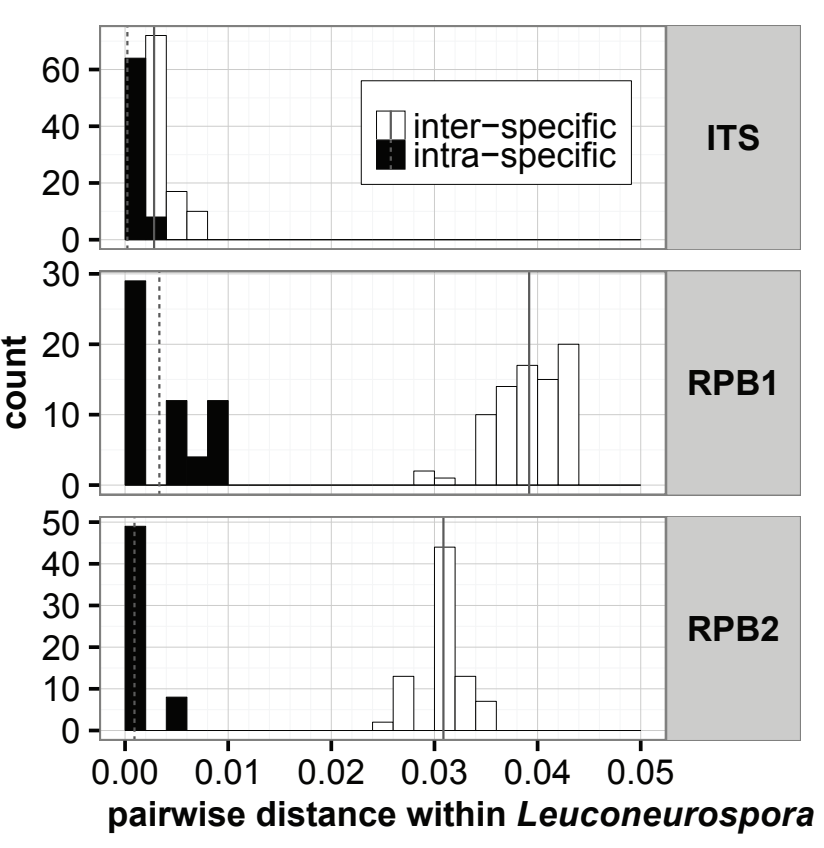

\begin{tabular}{|l|r} 
UAMH 11251 (MT-) & \\
UAMH 11459 (MT+) & \\
UAMH 11250 (M-) & \\
UAMH 11461 & Leuconeurospora \\
UAMH 11504 (M-) & polypaeciloides
\end{tabular}

\section{Leuconeurospora} capsici

UAMH 11463

UAMH 935

(T of Scopulariopsis capsici)

CBS 343.76 Leuconeurospora pulcherrima

98/75 UAMH 1527 Pseudeurotium hygrophilum (T) 99/100 CBS 329.36 Pseudeurotium zonatum

UAMH 5825 Pseudeurotium ovale var. ovale

$92 / 86$

UAMH 183 Geomyces asperulatus(T)

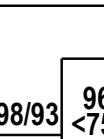

UAMH 10509 Pseudogymnoascus appendiculatus (T)

UAMH 10579 Pseudogymnoascus verrucosus (T)

97/87 UAMH 875 Pseudogymnoascus sp

UAMH 5339 Pseudogymnqascus_sp . 06 .manuscriptcentral.com/botany-pubs 


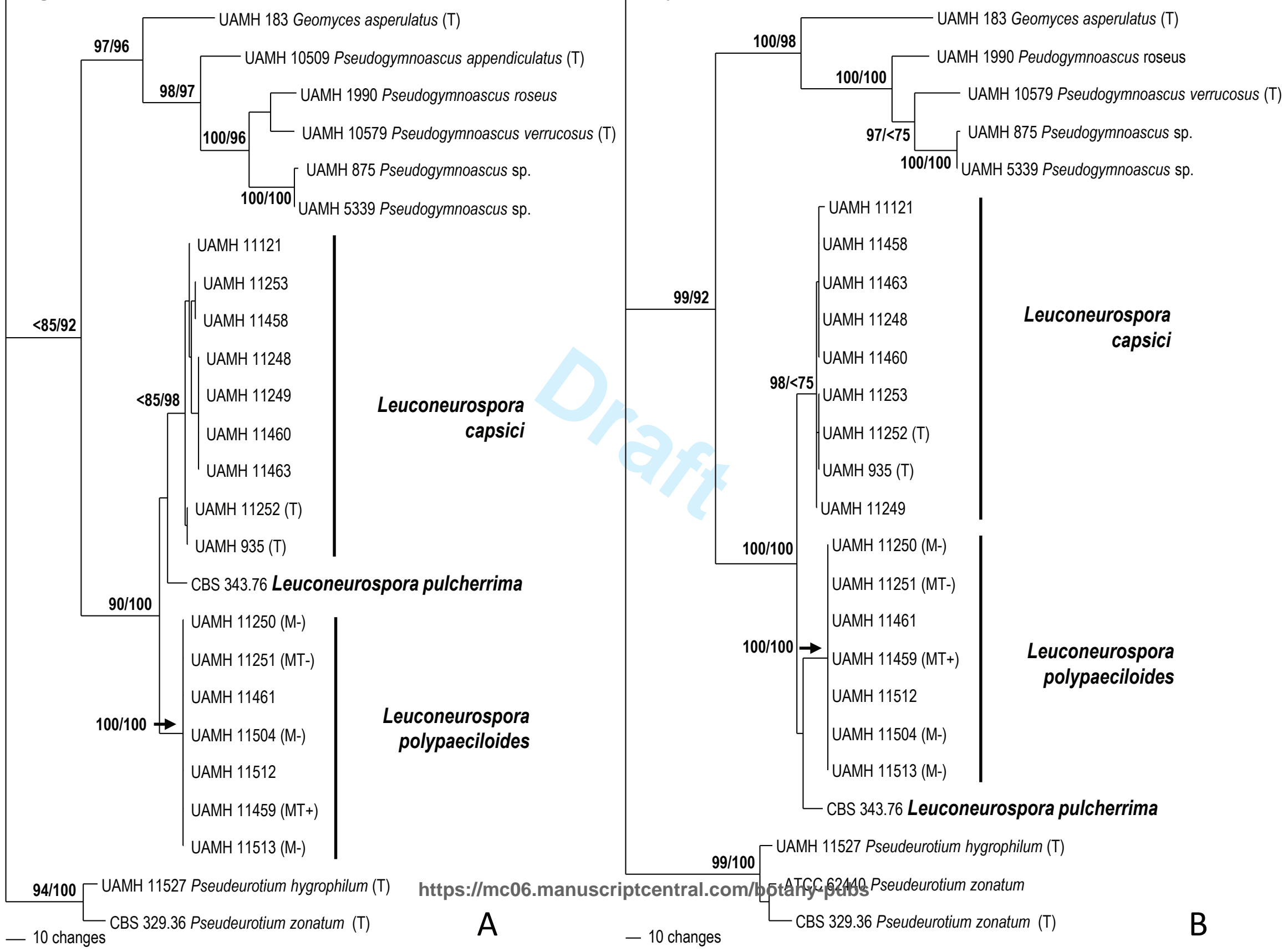

